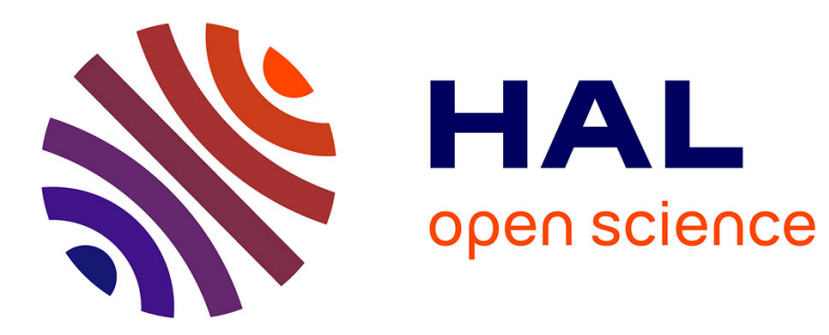

\title{
Mercury speciation in sediments at a municipal sewage sludge marine disposal site
}

\author{
E. Shoham-Frider, G. Shelef, N. Kress
}

\section{To cite this version:}

E. Shoham-Frider, G. Shelef, N. Kress. Mercury speciation in sediments at a municipal sewage sludge marine disposal site. Marine Environmental Research, 2007, 64 (5), pp.601. 10.1016/j.marenvres.2007.06.003 . hal-00562984

\section{HAL Id: hal-00562984 \\ https://hal.science/hal-00562984}

Submitted on 4 Feb 2011

HAL is a multi-disciplinary open access archive for the deposit and dissemination of scientific research documents, whether they are published or not. The documents may come from teaching and research institutions in France or abroad, or from public or private research centers.
L'archive ouverte pluridisciplinaire HAL, est destinée au dépôt et à la diffusion de documents scientifiques de niveau recherche, publiés ou non, émanant des établissements d'enseignement et de recherche français ou étrangers, des laboratoires publics ou privés. 


\section{Accepted Manuscript}

Mercury speciation in sediments at a municipal sewage sludge marine disposal site

E. Shoham-Frider, G. Shelef, N. Kress

PII:

S0141-1136(07)00076-1

DOI:

10.1016/j.marenvres.2007.06.003

Reference:

MERE 3129

To appear in:

Marine Environmental Research

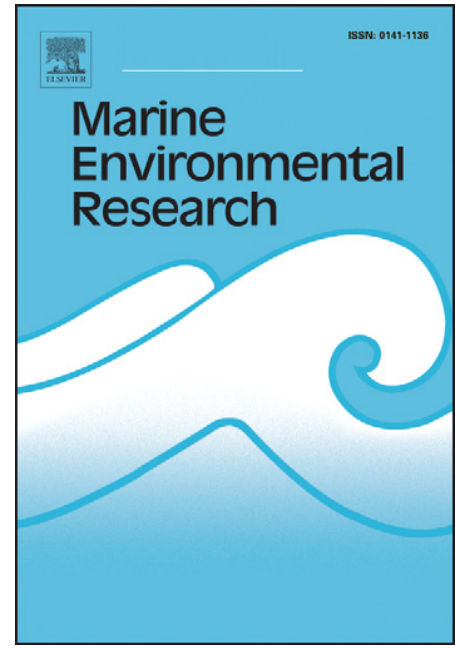

Received Date: $\quad 10$ September 2006

Revised Date: 13 June 2007

Accepted Date: $\quad 13$ June 2007

Please cite this article as: Shoham-Frider, E., Shelef, G., Kress, N., Mercury speciation in sediments at a municipal sewage sludge marine disposal site, Marine Environmental Research (2007), doi: 10.1016/j.marenvres.2007.06.003

This is a PDF file of an unedited manuscript that has been accepted for publication. As a service to our customers we are providing this early version of the manuscript. The manuscript will undergo copyediting, typesetting, and review of the resulting proof before it is published in its final form. Please note that during the production process errors may be discovered which could affect the content, and all legal disclaimers that apply to the journal pertain. 


\title{
ACCEPTED MANUSCRIPT
}

Mercury speciation in sediments at a municipal sewage sludge

marine disposal site

\author{
E. Shoham-Frider ${ }^{*}$, G. Shelef ${ }^{2}$, N. Kress ${ }^{1}$ \\ ${ }^{1}$ Israel Oceanographic and Limnological Research, National Institute of \\ Oceanography, PO Box 8030, Haifa 31080, Israel \\ ${ }^{2}$ Faculty of Civil \& Environmental Engineering, Technion - Israel Institute of \\ Technology, Technion City, Haifa 32000 Israel \\ * Corresponding author. Tel.: +972-4-8515202; fax: +972-4-8511911. E-mail \\ (E. Shoham-Frider)efrat@ocean.org.iladdress:
}

\begin{abstract}
Mercury speciation was performed in excess activated sewage sludge (ASS) and in marine sediments collected at the AAS disposal site off the Mediterranean coast of Israel in order to characterize the spatial and vertical distribution of different mercury species and assess their environmental impact. Total $\mathrm{Hg}(\mathrm{HgT})$ concentrations ranged between $0.19-1003 \mathrm{ng} / \mathrm{g}$ at the polluted stations and 5.7-72.8 $\mathrm{ng} / \mathrm{g}$ at the background station, while the average concentration in ASS was $1181 \pm 273 \mathrm{ng} / \mathrm{g}$. Only at the polluted stations did HgT concentrations decrease exponentially with sediment depth, reaching background values at $16-20 \mathrm{~cm}$, the vertical distribution resulting from mixing of natural sediment with ASS solids and bioturbation by large populations of polycheates.
\end{abstract}

Average Methyl $\mathrm{Hg}(\mathrm{MeHg})$ concentration in ASS was $39.7 \pm 7.1 \mathrm{ng} / \mathrm{g}$, ca. 3\% of the

HgT concentration, while the background concentrations ranged between 0.1-0.61 ng/g. MeHg concentrations in surficial polluted sediments were $0.7-5.9 \mathrm{ng} / \mathrm{g}$ (ca. $0.5 \%$ of the $\mathrm{HgT}$ ) and decreased vertically, similar to $\mathrm{HgT}$. A positive correlation between $\mathrm{MeHg}$ and $\mathrm{Hg}$ only at the polluted stations, higher $\mathrm{MeHg}$ concentrations at the surface of the sediment and not below the redoxline, and no seasonality in the concentrations suggest that the MeHg originated from the ASS and not from in situ methylation.. By 
doing selective extractions, we found that ca. $80 \%$ of the total $\mathrm{Hg}$ in ASS and polluted sediments was strongly bound to amorphous organo-sulfur and to inorganic sulfide species that are not bioavailable. The fractions with potential bioaccessible $\mathrm{Hg}$ had maximal concentrations in the range in which biotic effects should be expected.

Therefore although no bioaccumulation was found in the biota in the area, the concentration in the polluted sediments are not negligible and should be carefully

monitored.

Keywords: Mercury, Marine sediments, Sewage sludge, Bioavailability, Speciation, Eastern Mediterranean.

\section{Introduction}

Mercury is one of most studied metals in environmental and human health research. It has a very complex biogeochemical cycle, is bioaccumulative, can biomagnify along the food web and is toxic, impacting environment and man (Beckvar et al., 1996; Benoit et al., 1999a; Benoit et al.,1999b; Covelli et al.,1999; Hammerschmidt \& Fitzgerald, 2004; Horvat, 1997; Manaham, 2003; Morel et al.,1998; Sunderland et al., 2004; US EPA, 2000; Weber, 1993). Methylmercury (MeHg) is known to be the most toxic species of $\mathrm{Hg}$ and poses high risk to human health, mainly through the consumption of polluted fish (Baldi, 1997; Morel et al., 1998). Mercury methylation occurs mostly in anoxic sediments as a result of sulfate reducing bacteria (SRB) biosynthesis (Mason et al., 1993; Morel et al., 1998). Abiotic methylation may also occur in the environment, especially mediated by humic organic matter (Weber, 1993). MeHg enters the food web by fast diffusion and strong bonding to sulfhydryl 
groups present as part of biological molecules (Manaham, 2003). More than 90\% of total $\mathrm{Hg}$ in muscle tissue of top marine predators is $\mathrm{MeHg}$ (Baldi, 1997).

Transformations among different mercury species can have a major effect on the metal's mobility and bioavailability, affecting it's potential for methylation and hence bioaccumulation (Benoit et al., 1999a; Benoit et al., 1999b; Bloom et al., 2003; Hsu \& Sedlak, 2003; Morel et al., 1998). Bioavailable species like $\mathrm{HgCl}_{2}$ or polysulfide complexes $\left(\mathrm{HgS}_{\mathrm{x}}\right)$ can efficiently penetrate efficiently through cellular membranes (Morel et al., 1998), while species like organo-mercury complexes or $\mathrm{HgS}_{(\mathrm{S})}$ are not bioavailable (Benoit et al., 1999a; Hsu \& Sedlak, 2003).

In Israel, mercury is introduced into the marine environment by disposal of activated sewage sludge (ASS). The ASS is produced at the Dan region wastewater project that treats the municipal sewage of ca. 2 million inhabitants (Kress et al., 2004). Half of the mercury in the sewage can be traced to municipal households, dental clinics, drinking water supply system and industrial sources; especially caustic soda production. The source of the other half is unknown (Veber et al., 2001). Since 1987, approximately $16,000 \mathrm{~m}^{3}$ of excess ASS are discharged daily to the marine environment at a disposal site located $5 \mathrm{~km}$ off the Israeli Mediterranean coast at ca. $38 \mathrm{~m}$ water depth (Fig.1). Monitoring studies at the disposal site found total $\mathrm{Hg}(\mathrm{HgT})$ concentrations up to $1.4 \mu \mathrm{g} / \mathrm{g}$ (dry wt.) in the sediments (Kress et al., 2004), much higher than the normal $\mathrm{Hg}$ concentration found along the Mediterranean coast of Israel $(0.05 \mu \mathrm{g} / \mathrm{g})$. 


\section{ACCEPTED MANUSCRIPT}

Until now, only HgT concentrations in surface sediments were measured. No data exist on the vertical distribution of $\mathrm{Hg}$ concentrations in the sediments nor on the $\mathrm{Hg}$ species present at the disposal site, so it was impossible to estimate its environmental impact. Thus, the objective of this research was to identify the mercury species present in the ASS and in the sediments at the disposal site, characterize their vertical distribution, and assess, based on the results, their environmental impact.

\section{Materials and Methods}

\section{Study area}

Four sampling stations, from the outfall and northwards were chosen: Station 0 at the outfall, station 3 (200 $\mathrm{m}$ from the outfall), station 21 (1,500 $\mathrm{m}$ from the outfall) and station $29(5,500 \mathrm{~m}$ from the outfall) (Fig. 1). It is known that there is a preferential northwards dispersion of the ASS in agreement with the currents in the area (Kress et al., 2004), therefore the stations represent a gradient of decreasing ASS influence. Stations $0,3,21$ will be referred to as polluted stations and station 29 , not affected by the ASS, as the background station.

\section{Sampling}

The stations were sampled 6 times between 1999 and 2003 (August 1999, June 2000, August 2001, May 2002, October 2002 and September 2003) on board the Research

Vessel "Shikmona". During each survey, seawater, suspended particulate matter (SPM) and sediment cores for $\mathrm{Hg}$ analysis and speciation were sampled. Seawater for SPM was sampled by a membrane pump ("FLOWJET") into clean plastic containers. Seawater samples from the box-corer were sampled as well into polypropylene sterile 
tubes ("SARSTEDT"). Sediments were sampled by a $0.062 \mathrm{~m}^{2}$ box-corer with an

effective penetration of $40 \mathrm{~cm}$ (Ocean Instruments model $700 \mathrm{AL}$ ). Sub cores were taken from the box corer with hollow Perspex cylinders. The sub cores were sliced on board to $0.5-3 \mathrm{~cm}$ wide slices which were placed in clean plastic containers, frozen until chemical analysis in the laboratory.

Samples for $\mathrm{HgT}$ determination in seawater were preserved immediately upon sampling by oxidation with $0.1 \mathrm{~N} \mathrm{BrCl}$ (US EPA Method 1631, 2002). Seawater samples for HgT determination in SPM were filtered on board through a $0.45 \mu \mathrm{m}$ preweighted membrane filters (Herut \& Kress, 1997).

Activated sewage sludge (ASS) was sampled prior to its disposal at sea at the wastewater treatment plant into acid cleaned plastic containers. The ASS was freezedried for 48 hours after centrifugation (3500 RPM for $20 \mathrm{~min}$ ) and the solid deposit was separated. The dry ASS was homogenized and kept in clean dry plastic containers until analysis of $\mathrm{Hg}$ species. In addition, during 2002-2003, routine analysis of $\mathrm{HgT}$ in ASS was performed on a monthly basis $(n=151)$. In this case, the wet ASS was acidified to $\mathrm{pH} 2$ with $\mathrm{HCl}$ and kept refrigerated for up to a week until analysis of HgT. Water content was determined by drying in sub-samples.

\section{Laboratory analyses}


calculated after drying at $105^{\circ} \mathrm{C}$ overnight (SM-2540 B). Organic carbon was determined by potentiometric titration after digestion with potassium dichromate (Avnimelech ,1989; Gaudette et al.,1974). 


\section{ACCEPTED MANUSCRIPT}

Hg Speciation: in the laboratory, the frozen sediment samples were lyophilized for 48 hours and then dry sieved through a $1000 \mu \mathrm{m}$ sieve to extrude extraneous components such as seeds, broken shells, etc. Hg speciation was performed on dry sediment and dry ASS at least in duplicates. Speciation included measurements of $\mathrm{HgT}, \mathrm{MeHg}$ and ethyl $\mathrm{Hg}$, and $\mathrm{Hg}$ fractionation as measured by sequential selective extractions and by pyrolysis.

$\underline{\mathrm{HgT}}$ in seawater and wet ASS was measured by oxidation and cold vapor atomic fluorescence spectrometry (US EPA Method 1631). Dry sediments and ASS were analyzed after digestion with aqua regia for 1 hour at $160^{\circ} \mathrm{C}$ (Bloom, Preus et al., 2003; PSA Application 013). SPM filters were dried and digested with concentrated $\mathrm{HNO}_{3}$ at $140^{\circ} \mathrm{C}$ in stainless steel Teflon-lined pressure decomposition vessels (Herut

\& Kress, 1997). Hg analyses were performed by cold vapor atomic fluorescence spectrometry (CVAFS) with a Merlin Millenium system (PS Analytical, UK), after

$\mathrm{SnCl}_{2}$ reduction and purging with high purity argon. Quality control and quality assurance of the results was performed with standard reference materials from the US National Institute of Standards and Technology (NIST 2781), the National Research

Council of Canada (NRCC-MESS-2), and the International Atomic Energy Agency (IAEA-405). The standard reference materials were digested and analyzed in the same manner as the samples, with each analytical run. The results were within $5 \%$ of the certified values.

$\underline{\mathrm{MeHg}}$ was extracted from the sediment or the ASS as a halide salt with dichloromethane, followed by a cleanup procedure involving the formation of a water soluble adduct, its extraction into an aqueous phase which was separated and oxidized 


\section{ACCEPTED MANUSCRIPT}

by $\mathrm{BrCl}$ for $\mathrm{Hg}$ measurement (Cai, et al., 1997; Longbottom et al., 1973; Sakamoto et al., 1992). At the early stages of this work both $\mathrm{MeHg}$ and Ethyl $\mathrm{Hg}$ were measured by HPLC after solvent extraction (Cai et al., 1997; Hintelmann \& Wilken, 1993; PS Analytical, application 10.025, 2001; Wu, 1991). However, because no Ethyl Hg was detected in any of the samples, all organic $\mathrm{Hg}$ was assumed to be $\mathrm{MeHg}$. Therefore, the separation step by HPLC was skipped and the aqueous extract was oxidized with $\mathrm{BrCl}$ and $\mathrm{Hg}$ measured as in the seawater samples.

Selective Extractions: $\mathrm{Hg}$ in different biogeochemical fractions was measured by a five-step sequential extraction (Bloom et al., 2003). This method differentiates among different $\mathrm{Hg}$ species based on their biogeochemical behaviors and includes the following fractions: water-soluble species (F1) leached with deionized water; 'human stomach acid' soluble species (F2) leached with acetic acid; organo-chelated species (F3) leached with $1 \mathrm{~N} \mathrm{KOH}$; strong-complexed species (F4) leached with $12 \mathrm{~N} \mathrm{HNO}_{3}$ (elemental and/or $\mathrm{Hg}$ bound up in amorphous organo-sulfur, $\mathrm{Hg}-\mathrm{Ag}$ amalgams, or crystalline Fe/Mn oxide phases); and mercuric-sulfide (F5) leached with aqua-regia. After each step $\mathrm{Hg}$ was measured as $\mathrm{HgT}$ in the leaching media by CVAFS as described above. For quality control and determination of method recovery, each sample was analyzed for $\mathrm{HgT}$ as well. In all cases there were no significant

differences $(\mathrm{p}<0.05)$ between measured $\mathrm{HgT}$ and the sum of $\mathrm{Hg}$ concentrations in all fractions. Selective extractions were performed in duplicate samples from sediment cores sampled in May 2002, October 2002, and September 2003. Speciation was performed also in the following certified reference materials (CRM): domestic sludge (NIST 2781) and estuarine sediment (IAEA-405). 


\section{ACCEPTED MANUSCRIPT}

Pyrolysis: Pyrolitic Hg analyses were performed in 16 representative samples by Dr.

Harald Biester (Institute of Environmental Geochemisty, University of Heidelberg, Germany) by the method described in Biester \& Scholz, 1997 and; Biester et al., 2000. The purpose of the analyses was to identify qualitatively the presence or absence of some $\mathrm{Hg}$ species in the samples.

\section{Results and Discussion}

\section{Water and Organic Carbon content in the sediments}

Water content in the sediments is a simple but effective parameter to identify ASS

presence, since ASS is essentially a liquid (99\% water content) that coagulates and sinks to the bottom following contact with seawater (Hunt, 1990). The average water content in the sediments at the background station was $33.3 \% \pm 8 \%$ from the surface and down to $25 \mathrm{~cm}$ depth. At the polluted stations maximal water content (70-80\%) was observed at the surface, and decreased gradually to background values at $5-10 \mathrm{~cm}$ depth (Fig.2). The content of water at the upper layer of the polluted stations was higher in fall. A similar pattern was observed for organic carbon concentrations: homogeneous vertical profile at the background station $(0.4-0.95 \%)$, in contrast to a decreasing gradient at the polluted stations with maximal values at the surface $(6 \%)$ down to background concentration at a depth of 10-20 cm (Fig.2). Also considering that the concentration of organic carbon in the ASS was $31.4 \% \pm 6.6 \%(n=4)$, these results indicate mixing between sediment and ASS down to $10-20 \mathrm{~cm}$ at the polluted stations. In the spring the fraction of the ASS in the mixed layer was smaller than in the fall. This is in agreement with the fact that ASS accumulates from spring to fall at the site while winter storms resuspend and disperse the ASS (Kress et al., 2004). 
$\underline{\text { Total Hg (HgT) }}$

$\mathrm{HgT}$ in SPM from the polluted stations was in the range of 206-1621 ng/g. This range corresponds to $0.2-6.1 \mathrm{ng} / \mathrm{L}$ in seawater with an average concentration of $4.5 \mathrm{mg} / \mathrm{L}$

SPM. The concentrations of $\mathrm{HgT}$ in the seawater from just above the sediment surface were up to $100 \mathrm{ng} / \mathrm{L}$. The concentrations of $\mathrm{HgT}$ in the seawater at the ASS plume were $22.0 \pm 17.6 \mathrm{ng} / \mathrm{L}$ (Shoam-Frider, 2005) These concentrations are very low compared to those measured in the ASS and sediments.

Average HgT concentration in the ASS was $1181 \pm 273 \mathrm{ng} / \mathrm{g}$, dry weight $(n=151)$. In the sediments, concentrations ranged between $0.19-1003 \mathrm{ng} / \mathrm{g}$ at the polluted stations and 5.7-72.8 $\mathrm{ng} / \mathrm{g}$ at the background station, with averages of $263 \pm 239 \mathrm{ng} / \mathrm{g}(\mathrm{n}=132)$ and $24.8 \pm 12.1 \mathrm{ng} / \mathrm{g}(n=51)$, respectively. Table 1 presents the average (6 surveys) vertical distribution of $\mathrm{HgT}$ in the sediments down to $30 \mathrm{~cm}$ depth. At the background station, $\mathrm{HgT}$ concentration was essentially constant at all depths, at background levels (22.5 ng/g, Table 1). At the polluted stations, the depth distribution of $\mathrm{HgT}$ in the sediments showed an exponential decrease with depth (Fig.3), reaching background levels at 16-20 $\mathrm{cm}$ depth, and was similar to the depth distribution of organic carbon.

The concentrations decreased probably due to natural mixing processes of sediment with ASS solids deposited at the site. Moreover, large populations of polycheates $\left(3,000-10,000\right.$ specimens $\left./ 0.0124 \mathrm{~m}^{3}\right)$ are usually observed in the spring at the polluted stations (Kress et al., 2004), therefore it is reasonable to assume that bioturbation also plays a major role in the mixing. It is known that oligochaetes and other epifaunal species are responsible for the active sediment mixing down to about $10 \mathrm{~cm}$ (Thibodeaux \& Bierman, 2003). 
It can be seen (Fig.3) that the vertical decrease of $\mathrm{HgT}$ concentrations with sediment depth was similar at stations 0 and 3 and different at station 21 which had a more moderate decrease. For instance, at $10 \mathrm{~cm}$ depth, the $\mathrm{HgT}$ concentrations were ca.100 ppb at stations 0 and 3 while ca. $300 \mathrm{ppb}$ at station 21 . This shows that a higher accumulation of $\mathrm{HgT}$ occurs at station 21, located $1500 \mathrm{~m}$ northwards from the outfall, than at stations 0 and 3, located closer to the outfall (Fig.1). The maximal accumulation of $\mathrm{Hg}$ was found at station 21 and not at the outfall, in agreement with dispersion models (Hunt, 1990) and with the average northward current along the Israeli shore with velocities between 15 to $90 \mathrm{~cm} \mathrm{~s}^{-1}$ (Rosentraub, 1990). The accumulation decreased from station 21 northwards and at station 29 (the background, located $5.5 \mathrm{~km}$ northwards from the outfall) the $\mathrm{Hg}$ concentrations reached natural values.

No seasonal differences in $\mathrm{HgT}$ concentrations were observed $(\mathrm{p}<0.05)$ at the polluted stations, even though it is known that during winters the sewage sludge is dispersed from the area and it re-accumulates from spring to winter (Kress et al., 2004). Lower

HgT concentrations were measured in the winter, compared to spring and fall. It is not clear which mechanism causes some of the $\mathrm{Hg}$ to remain in the area. One possible explanation could be the retention of colloidal phase $\mathrm{Hg}$ bound to organo-sulfur in pore waters in the area while $\mathrm{Hg}$ associated with solid particles is dispersed (Guentzel et al., 1996; Sunderland et al., 2006).

\section{$\underline{\text { Methyl Hg (MeHg) }}$}

Average MeHg concentration in the ASS was 39.68 $\pm 7.06 \mathrm{ng} / \mathrm{g}$ (dry wt., $n=4$ ) and it constituted about 3\% of the $\mathrm{HgT}$ present in the ASS. MeHg in sewage sludge might 
originate from biotic and/or abiotic methylation processes. Biotic methylation is a bacterial process that involves the growth factor $\mathrm{B}_{12}$, which is the main substrate for MeHg synthesis (Baldi, 1997). It is known that the $\mathrm{B}_{12}$ is produced by a wide range of aerobic and anaerobic bacteria; nearly all are present in sewage sludge (Metcalf \& Eddy, 2003). Abiotic methylation of $\mathrm{Hg}$ involves organic humic matter, which is present in the aquatic environments and in sewage (Weber, 1993).

At the polluted sediments the $\mathrm{MeHg}$ constituted an average $0.46 \%$ of $\mathrm{HgT}$. $\mathrm{MeHg}$ concentrations in the surface of the sediments ranged between $0.7-5.90 \mathrm{ng} / \mathrm{g}$ with no seasonal differences, and changed with sediment depth a pattern similar to HgT (Fig. 4). A positive correlation was found between $\mathrm{MeHg}$ and $\mathrm{HgT}$ (Fig. 5). On the other hand, at the background station MeHg concentrations (0.09-0.61 ng/g) were higher in fall than in spring, and constituted $2.5 \%$ and $0.23 \%$ of $\mathrm{HgT}$, respectively. No significant correlation between $\mathrm{MeHg}$ and $\mathrm{HgT}$ was found at the background stations.

Several findings in this study suggest that $\mathrm{MeHg}$ found in the sediments of the polluted stations originated from the ASS and not from in situ methylation: a positive correlation between $\mathrm{MeHg}$ and $\mathrm{HgT}$, higher $\mathrm{MeHg}$ concentrations at the surface of the sediment and not below the redoxline, and the lack seasonality of the concentrations. Past studies show that $\mathrm{MeHg}$ concentrations are dependent mostly on environmental factors (i.e. temperature, redox potential, organic carbon, sulfide) Kelly et al., 1995), however, positive correlations between $\mathrm{HgT}$ and $\mathrm{MeHg}$ concentrations in sediments were found in other marine areas where current and historical pollution by $\mathrm{Hg}$ was documented ( Hammerschmidt \& Fitzgerald, 2004, Sunderland et al., 2004; Sunderland et al., 2006 ). In this study, a positive correlation between $\mathrm{MeHg}$ and $\mathrm{HgT}$ 


\section{ACCEPTED MANUSCRIPT}

was found only at the polluted stations and not at the background station.

Furthermore, the relation between $\mathrm{HgT}$ and $\mathrm{MeHg}$ was more significant at station 0 $\left(\mathrm{R}^{2}=0.76, \mathrm{p}<0.0001\right.$, Fig. 5) positioned at the outfall itself, where HgT concentration and accumulation of sludge were not maximal, but the sewage sludge there is "fresh".

It is known that methylation is mediated by $\mathrm{SRB}$ and that $\mathrm{MeHg}$ will occur below the redoxline where the sediments become reduced (Davis et al., 1997; Gagnon et al., 1996). In this study, maximal MeHg concentrations were found at the surface of the sediments of the polluted stations. Moreover, there were no seasonal differences in MeHg concentrations at the polluted stations in contrast to other studies (Bloom et al.,

1999; Covelli et al., 1999; Leermakers et al., 2001). At the background station (St.29), MeHg concentrations were significantly higher in fall than in spring while HgT was essentially constant. The higher concentrations of $\mathrm{MeHg}$ in the fall can be the result of higher natural methylation when water temperatures are higher (Hammerschmidt \& Fitzgerald, 2004; Leermakers et al., 2001).

\section{$\underline{\mathrm{Hg} \text { in biogeochemical fractions }}$}

$\mathrm{Hg}$ concentrations in the different biogeochemical fractions of polluted sediments, background sediment and ASS are presented in Tables 2-3 and Figure 6. Pyrolysis results showed that $\mathrm{Hg}$ was released mostly in the temperature range of 230$280^{\circ} \mathrm{C}$, typical to $\mathrm{Hg}$ associated with humic acids (organic fraction). In a few cases, $\mathrm{Hg}$ was released at $300-340^{\circ} \mathrm{C}$, typical of $\mathrm{Hg}$ release from cinnabar. None of the polluted sediment samples contained $\mathrm{Hg}^{0}$ which is typically released at a temperature

of $100^{\circ} \mathrm{C}$ (Biester \& Scholz, 1997; Biester et al., 2000). 
The selective extractions results showed that in all samples $99 \%$ of the $\mathrm{Hg}$ was located at fractions F3-F5 (Fig. 6, Table 2); the organo-chelated species (F3), the strong-complexed species (F4) and the mercuric-sulfide (F5). However, there were differences among the relative contributions of the F3 and F4 fractions in the ASS, the background station and the polluted stations (Table 3). The relative content of F3 was the highest at the background station, followed by the ASS and the polluted stations. The F4 relative content was the highest at the polluted stations, followed by the ASS and the lowest at the background station. Dominance of the F4 fraction was also

found in marine sediments from the bay of Trieste with HgT concentration of 132 ppm present mostly as mercury sulfides (Kim et al., 2003). There were no significant differences in the F5 content between the background and the polluted stations. The relative distribution of $\mathrm{Hg}$ in ASS was very similar to that found in sludge CRM while relative distribution in the background station was very similar to estuarine sediment

CRM and to that found in natural sediments elsewhere (Bloom et al., 2003). The relative distribution of the F3-F5 fractions in polluted stations had a high similarity to that at the ASS and differed significantly from the background, indicating the ASS as the source of the $\mathrm{Hg}$ in the area.

The F3 fraction in environmental samples is known to contain mainly $\mathrm{Hg}$ associated with humic organic matter and with living and dead biota (Bloom et al., 2003). The F4 fraction, which contained more than $70 \%$ of the $\mathrm{HgT}$ at the polluted stations and the ASS, may include $\mathrm{Hg}^{0}, \mathrm{Hg}$ bound to amorphous organo-sulfur, $\mathrm{Hg}-\mathrm{Ag}$ amalgams, or crystalline Fe/Mn oxide phases (Bloom et al., 2003; Revis et al., 1989). Pyrolysis of representative samples in our study found that most of the $\mathrm{Hg}$ was bonded to humic acids and no presence of $\mathrm{Hg}^{0}$ was detected. These findings suggest that the $\mathrm{Hg}$ in the 
$\mathrm{F} 4$ fraction is bonded to humic matter through organic $\mathrm{S}$ functional groups that are stronger and more stable than other functional groups like carboxylic or oxide groups (Allard \& Arsenie, 1991; Mierle \& Ingram, 1991; Weber, 1993). Recent advances in spectroscopic techniques and indirect evidence suggest strong interactions between $\mathrm{Hg}$ and dissolved organic matter, most likely through covalent bonding at thiol-type functional groups in organic matter (Ravichandran, 2004). Evaluation of the bondstrength between $\mathrm{Hg}$ and humic and fulvic acids found a range of values which can be explained only if complexation involves reduced RSH groups (Amirbahman et al., 2002; Hintelmann et al.,, 1997; Karlsson \& Skyllberg, 2003). In addition, several studies (Di Giulio \& Ryan, 1987; Dyrssen \& Wedborg, 1991; Hsu \& Sedlak, 2003; Laurier et al., 2003; Ravichandran et al., 1998; Ravichandram, 2004) have showed that $\mathrm{Hg}$, present in organic-rich matrixes like sludge or polluted sediments, forms strong complexes with S-containinig organic ligands, and these complexes are stable, inert and unavailable to chemical and biological transformations, like methylation. Therefore, it is reasonable to assume that $\mathrm{Hg}$ bonded to non- $\mathrm{RSH}$ functional groups in humic acids would be released more easily and be present in the F3 fraction, while the stronger S-bonded $\mathrm{Hg}$ in humic acids would be present in the F4 fraction. It is hypothesized that the $\mathrm{Hg}$ present in the F4 fraction, in the ASS and polluted sediments (more than $75 \%$ ), is not readily bioavailable.

Fluctuations with no clear tendencies were observed in the vertical distribution of the relative $\mathrm{Hg}$ content in the $\mathrm{F} 3-\mathrm{F} 5$ fractions in the sediments from the polluted stations

(Fig. 7). Only the relative $\mathrm{Hg}$ content in the F1 fraction (the water-soluble, mobile, bioavailable $\mathrm{Hg}$ species) increased significantly with increased depth of the sediment

(Fig. 7; $\mathrm{n}=39, \mathrm{p}<0.0001$ ) but the concentrations remained very low. A weak but 
significant negative correlation was found as well between the F1 and F5 fractions

(Fig.8) and when a multi variable regression was applied $(\mathrm{n}=38, \mathrm{p}<0.05$, not presented), a significant negative relation was found between the F1 fraction and the other three fractions together $(\mathrm{F} 3+\mathrm{F} 4+\mathrm{F} 5)$. That leads us to assume that a small

portion of the $\mathrm{Hg}$ released from the other fractions, and especially the F5 fraction remains as water-soluble species in the sediment. When the relationships between the

fractions were tested by linear regression, a negative correlation was also observed between F5-F4 and F4-F3 (Fig. 8). No correlation was observed between F5 and F3. These relationships showed that $\mathrm{Hg}$ could be exchanged between F3-F4, F4-F5, and F1-F3, F4, F5. This dynamics is in agreement with the differences in the relative content of the fractions found among the different samples: the content of F3 decreased in the polluted sediments compared to the AAS while F4 increased. It seems that at sea the organic fraction (F3) decomposes and $\mathrm{Hg}$ is re-adsorbed mostly

by the F4 fraction.

\section{$\underline{\text { Bioavailability and environmental impact }}$}

Speciation is the key to understanding mercury behavior and to assess it's accessibility, bioaccumulation and toxicity. Speciation determinations were performed

in ASS and sediments. Although no speciation test was performed in seawater, the $\mathrm{HgT}$ concentrations in the seawater (maximum $0.1 \mu \mathrm{g} / \mathrm{L}$ ) were lower than the Israeli guideline of $0.16 \mu \mathrm{g} / \mathrm{L}$ for Mediterranean seawater and lower than the US EPA criteria ( 0.9 and $1.8 \mu \mathrm{g} / \mathrm{L}$ for continuous and maximum concentrations, respectively) (US EPA, 2002). Therefore, $\mathrm{Hg}$ in seawater is not expected to be detrimental to the environment. 
Mercury speciation in ASS and sediments at the marine outfall showed that most of the $\mathrm{Hg}$ (ca. 80\%) was strongly bound to amorphous organo-sulfur (F4) and to sulfide (F5). This Hg is neither available nor accessible directly to the biota, nor is it available to methylation processes (Bloom et al., 2003). The F1-F2 fractions that contained the bioaccessible $\mathrm{Hg}$ in the polluted sediments and the F3 fraction that can decompose and release accessible $\mathrm{Hg}$ to the environment contained $0.1-2.4 \%$ and $20-24 \%$ of the $\mathrm{HgT}$, with maximal concentrations of $10 \mathrm{ng} / \mathrm{g}$ and $227 \mathrm{ng} / \mathrm{g}$, respectively. Long et al. (1995) suggested marine sediment guidelines, based on the potential to induce toxic effects in marine organisms: ERL (Effects Range Low) and ERM (Effects Range Median) that for $\mathrm{HgT}$ are 150 and $710 \mathrm{ng} / \mathrm{g}$, respectively. These guidelines were adopted by many countries and serve as a basis in risk assessment. In this study, the maximal concentration of $\mathrm{Hg}$ in the bioaccessible fractions, F1-F3, of $240 \mathrm{ng} / \mathrm{g}$ was between the ERL-ERM, therefore biotic effects should be expected and the concentration in the polluted sediments are not negligible.

$\mathrm{MeHg}$ is the species that is taken up by marine organisms, bioaccumulates and biomagnifies. This study suggests that the $\mathrm{Hg}$ in $\mathrm{F} 3$ was not available to methylation in contrast to other studies (Bloom et al., 2003), and that the ASS was the source of $\mathrm{MeHg}$ found in the polluted sediments. An anoxic incubation of polluted sediments from the study area with ASS in seawater showed no significant changes in $\mathrm{MeHg}$ concentrations from 6 weeks to 5 months (Shoam-Frider, 2005).

The low concentrations of $\mathrm{MeHg}$ in the polluted sediments $(0.7-5.90 \mathrm{ng} / \mathrm{g})$ and the assumption of a lack of in-situ methylation, are in agreement with the fact that until 


\section{ACCEPTED MANUSCRIPT}

today no accumulation of mercury was found in marine biota collected at the ASS marine outfall area (Kress, Galil \& Herut, 2003). The concentrations $(<5-100$ ng/g wet weight) were similar to those found in the same species at a control areas.

Assuming that all of the $\mathrm{Hg}$ is in the form of $\mathrm{MeHg}$, it is still much lower than the strict criterion of $300 \mathrm{ng} / \mathrm{g} \mathrm{MeHg}$ fish tissue (wet wt.) (US EPA, 2001), indicating no $\mathrm{Hg}$ threat to human health due to the consumption of fish from the area. Nevertheless, the bioavailable $\mathrm{MeHg}$ reaching the marine environment directly with the ASS and the concentrations found at the bioaccessible fractions might pose an environmental risk and should be carefully monitored.

\section{Acknowledgements}

We thank the Dan Region Wastewater project for funding this research. We are grateful to the captain and crew of the R/V Shikmona for their devoted work at sea. The thorough reviews by two anonymous reviewers helped improve the manuscript and are greatly appreciated.

\section{References}

Allard, B. \& Arsenie, I. (1991). Abiotic reduction of mercury by humic substances in aquatic system- an important process for the mercury cycle. Water Air Soil Pollut., 56,

$457-464$

Amirbahman, A., Reid, A.L., Haines, T.A., Kahl, J.S. \& Arnold, C. (2002). Association of methylmercury with dissolved humic acids. Environ. Sci. Technol., 36,

690-695. 
Avnimelech, Y. (1989). Modeling the accumulations of organic matter in the sediments of a newly constructed reservoir. Water Research, 23, 1327-1329.

Baldi, F. (1997). Microbial transformation of mercury species and their importance in the biogeochemical cycle of mercury. In: Metal ions in biological systems - mercuty and its effects on environment and biology. Edited by Sigel, A. and Sigel, H., Marcel

Dekker Inc., Vol. 34, 213-248.

Beckvar, N., Field, J., Salazar, S., \& Hoff, R. (1996). Contaminants in Aquatic Habitats at Hazardous Waste Sites: Mercury. NOAA Technical Memorandum, NOS

ORCA 100.

Benoit, J.M., Gilmour, C.C.,; Mason, R.P.,\& Heyes, A. (1999a). Sulfide controls on mercury speciation and bioavailability to methylating bacteria in sediment pore waters. Environ. Sci. Technol., 33, 951-957.

Benoit, J.M., Mason, R.P., \& Gilmour, C.C. (1999b). Estimation of mercury-sulfide speciation in sediment pore waters using octanol-water partitioning and implications for availability to methylating bacteria. Environ. Toxicol. Chem., 18 (10), 2138-2141.

Biester, H. \& Scholz, C. (1997). Determination of mercury binding forms in contaminated soils: mercury pyrolysis versus sequential extractions. Environ. Sci.

Technol., 31, 233-239. 
Biester, H., Gosar, M., \& Covelli, S. (2000). Mercury speciation in sediments affected by dumped mining residues in the drainage area of the Indija mercury mine,

Slovenia. Environ. Sci. Technol., 34, 3330-3336.

Bloom, N.S., Gill, G.A., Cappellino, S., Dobbs, C., Mcshea, L., Driscoll, C., Mason, R. \& Rudd, J. (1999). Speciation and cycling of Mercury in Lavaca bay, Texas, sediments. Environ. Sci. Technol., 33, 7-13.

Bloom, N.S., Preus, E., Katon, J., \& Hiltner, M. (2003). Selective extractions to assess the biogeochemically relevant fractionation of inorganic mercury in sediments and soils. Anal. Chim. Acta, 479, 233-248.

Bloom, N.S., Moretto, L.M., Scopece, P. \& Ugo, P. (2004). Seasonal cycling of mercury and monomethyl mercury in the in the Venice Lagoon (Italy). Mar. Chem.,

91, 85-99.

Cai, Y., Jaffe', R., \& Jones, R. (1997). Ethylmercury in the soils and sediments of the Florida Everglades. Environ. Sci. Technol., 31 (1), 302-305.

Covelli, S., Faganeli, J., Horvat, M., \&; Brambati, A. (1999). Porewater distribution and benthic flux measurements of mercury and methylmercury in the gulf of Trieste (northern Adriatic Sea). Estuar. Coast. Shelf Sci., 48, 415-428. 
Davis, A., Bloom, N.S. \& Que Hee, S.S. (1997). The environmental geochemistry and bioaccessibility of mercury in soils and sediments: A Review. Risk Anal., 17 (5), 557-

569.

Di Giulio, R.T. \& Ryan, E. (1987). Mercury in soils, sediments, and clams from a North Carolina peatland. Water Air Soil Pollut., 33, 205-219.

Dyrssen, D. \& Wedborg, M. (1991). The Sulphur-Mercury(II) system in natural waters. Water Air Soil Pollut., 56, 507-519.

Gagnon C., Pelletier E., Mucci A. \& Fitzgerald W.F. (1996). Diagenetic behavior of methylmercury in organic-rich coastal sediments. Limnol. Oceanogr., 41 (3), 428-434.

Gaudette, H.E., Flight, W.R., Toner, L., \& Folger, D.W. (1974). An inexpensive titration method for the determination of organic carbon in recent sediments. Journal of Sedimentary Petrology, 44, 249-253.

Gilmour, C.C. \& Henry, E.A. (1991). Mercury methylation in aquatic systems affected by acid deposition. Environ. Pollut., 71, 131-169.

Guentzel, J.L., Powell, R.T., Landing, W.M., \& Maso, R.P. (1996). Mercury associated with colloidal material in an estuarine and an open-ocean environment. Mar. Chem., 55, 177-188. 


\section{ACCEPTED MANUSCRIPT}

Hammerschmidt, C.R., \& Fitzgerald, W.F. (2004). Geochemical controls on the production and distribution of methylmercury in near-shore marine sediments.

Environ. Sci. Technol., 38, 1487-1495.

Herut, B.\& Kress, N. (1997). Particulate metals contamination in the Kishon river estuary, Israel. Mar. Pollut. Bull., 34, 706-711.

Hintelmann, H., \& Wilken, R.D. (1993). The analysis of organic mercury compounds using liquid chromatography with online atomic fluorescence spectrometric detection. Applied Organometallic Chemistry, Vol. 7, 173-180.

Hintelmann, H., Welbourn, P.M. \& Evans, R.D. (1997). Measurement of complexation of methylmercury(II) compounds by freshwater humic substances using equilibrium dialysis. Environ. Sci. Technol., 31, 489-495.

Horvat, M. (1997). Mercury behavior in estuarine and coastal environment. Fourth international conference on water pollution. Water Pollution IV, Modelling, Measuring and Prediction. Editors: Rajar, R. and Brebbia, C.A.

Hsu, H. \& Sedlak, D.L. (2003). Strong Hg(II) complexation in municipal wastewater effluent and surface water. Environ. Sci. Technol., 37, 2743-2749.

Hunt, J.R. (1990). Particle removal by coagulation and settling from a waste plume. In: Oceanic Processes in Marine Pollution, edited by Baumgartner, D.J. and Duedall, I.W., Vol.6, 109-119. 
Karlsson, T. \& Skyllberg, U. (2003). Bonding of ppb levels of methyl mercury to reduced sulfur groups in soil organic matter. Environ. Sci. Technol., 37, 4912-4918.

Kelly, C.A., Rudd, J.W.M., Louis, V.L.St., \& Heyes, A. (1995). Is total mercury concentration a good predictor of methyl mercury concentration in aquatic systems?

Water Air Soil Pollut., 80, 715-724.

Kim, C.S., Bloom, N.S., Rytuba, J.J. \& Brown, G.E., JR. (2003). Mercury speciation by X-ray absorption fine structure spectroscopy and sequential chemical extractions: a comparison of speciation methods. Environ. Sci. Technol., 37, 5102-5108.

Kress, N., Galil, B., and Herut, B. (2003). The influence of activated sewage sludge on the marine environment. Results of metal determination in commercial fish caught on May 2003 at the sewage sludge discharge area. IOLR Rep.H36/2003, (in Hebrew).

Kress, N.; Herut, B. \& Galil, B.S. (2004). Sewage sludge impact on sediment quality and benthic assemblages off the Mediterranean coast of Israel - a long-term study. Mar. Environ. Res., 57 (3), 213-233.

Laurier, F.J.G., Cossa, D., Gonzalez, J.L., Breviere, E. \& Sarazin, G. (2003). Mercury transformations and exchanges in a high turbidity estuary: The rule of organic matter and amorphous oxyhydroxides. Geochim. Cosmochim. Acta, 67 (18), 3329-3345. 


\section{ACCEPTED MANUSCRIPT}

Leermakers, M., Galletti, S., De Galan, S., Brion, N. \& Baeyens, W. (2001). Mercury in the southern sea and Scheldt estuary. Mar. Chem., 75, 229-248.

Long, E.R., Macdonald, D.D., Smith, S.L. \& Calder, F.D. (1995). Incidence of adverse biological effects within ranges of chemical concentrations in marine and estuarine sediments. Environmental Management Vol. 19, No. 1, pp. 81-97.

Longbottom, J.E., Dressman, R.C., \& Lichtenberg, J.J. (1973). Gas chromatographic determination of methyl mercury in fish, sediment and water. Journal of the AOAC,

56 ( 6), 1297-1303.

Manaham, S.E.. (2003) Toxicological Chemistry and Biochemistry. $3^{\mathrm{RD}}$ Edition, Lewis Publishers.

Mason, R.P., Fitzgerald, W.F., Hurley, J., Hanson, A.K., Donaghay, P.L., \& Sieburth, J.M. (1993). Mercury biogeochemical cycling in a stratified estuary. Limnol. Oceanogr., 38(6), 1227-1241.

Metcalf and Eddy (2003). Wastewater Engineering- Treatment and Reuse. $4^{\text {th }}$ Edition, McGraw Hill.

Mierle, G. \& Ingram, R. (1991). The role of humic substances in the immobilization of mercury from watersheds. Water Air Soil Pollut., 56, 349-357. 


\section{ACCEPTED MANUSCRIPT}

Morel, F.M.M., Kraepeil, A.M.L., \& Amyot, M. (1998). The chemical cycle and bioaccumulation of mercury. Annu. Rev. Ecol. Syst., 29, 543-66.

PS Analytical, application 10.025 (2001). Mercury Speciation System.

PS Analytical Application note 013 (2001). Mercury determinations in soils, sediment

\& sludge samples.

Ravichandran, M., Aiken, G.R., Reddy, M.M. \& Ryan, J.N. (1998). Enhanced dissolution of cinnabar (mercuric sulfide) by dissolved organic matter isolated from the Florida Everglades. Environ. Sci. Technol., 32, 3305-3311.

Ravichandran, M. (2004). Interactions between mercury and dissolved organic matterA review. Chemosphere, 55, 319-331.

Revis, N.W., Osborne, T.R., Holdsworth, G., Hadden, C. (1989). Distribution of mercury species in soil from a mercury contaminated site. Water Air Soil Pollut., 45,

$105-113$.

Rosentraub, Z. (1990). Investigation of the currents on the continental shelf of Israel. Israel Oceanographic and Limnological Research, Report H18/90. (In Hebrew)

Sakamoto, H., Tomiyasu, T., \& Yonehara, N. (1992). Differential determination of organic mercury, mercury (II) oxide and mercury (II) sulfide in sediments by cold vapor atomic absorption spectrometry. Anal. Sci., 8, 35-39. 
Shoham-Frider, 2005. Chemical speciation of mercury in sewage sludge before and after marine disposal: Assessment of the fate of mercury in the marine environment.

PhD Thesis.

Standard Methods for the examination of water and wastewater, $20^{\text {th }}$ edition, (1998). SM-2540 B; Total solids dried at $103-105^{\circ} \mathrm{C}$.

Sunderland, E.M., Gobas, F.A.P.C., Heyes, A., Branfireun, B.A., Bayer, A.K., Cranston, R.E., \& Parsons, M.B. (2004). Speciation and bioavailability of mercury in well-mixed estuarine sediments. Mar. Chem., 90, 91-105.

Sunderland, E.M., Gobas, F.A.P.C., , Branfireun, B.A., \& Heyes, A.. (2006).

Environmental controls on the speciation and distribution of mercury in coastal sediments. Mar. Chem., 102, 111-123.

Thibodeaux, L.J. \& Bierman, V.J. (2003). The bioturbation driven chemical release process. Environ. Sci. Technol., 253-258.

U.S. Environmental Protection Agency (EPA) (2000). Mercury research strategy. Office of Research and Development. EPA/600/R-00/073

U.S. Environmental Protection Agency (EPA) (2001). Mercury Update: Impact on Fish Advisories. EPA-823-F-01-011. 
U.S. Environmental Protection Agency (EPA) (2002). Method 1631, Revision E:

Mercury in water by oxidation, purge and trap, and cold vapor atomic fluorescence

spectrometry.

Veber, B., Shelhav, U. \& Fridler, E., (2001). Mass balance of pollutants in the Shafdan sewage. The state of Israel- the environmental quality ministry (in Hebrew).

Weber H. J. (1993). Review of possible paths for abiotic methylation of Mercury (II) in the aquatic environment. Chemosphere, 26 (11), 2063-2077.

Wu, J.C.G. (1991). Interfacing HPLC and cold-vapor AA with on-line preconcentration for mercury speciation. Spectroscopy Letters, 24(5), 681-697. 
Table 1: Concentrations of $\mathrm{HgT}$ (ng/g, dry wt.) in sediment cores from the polluted $(0,3,21)$ and background (29) stations.

\begin{tabular}{|c|c|c|c|c|c|c|c|c|c|c|c|c|}
\hline & \multicolumn{10}{c|}{ HgT ng/g dry weight } \\
\hline Depth & \multicolumn{3}{|c|}{ Station 0 } & \multicolumn{3}{c|}{ Station 3 } & \multicolumn{3}{c|}{ Station 21 } & \multicolumn{3}{c|}{ Station 29 } \\
\hline cm & $n$ & Average & STD & $n$ & Average & STD & $n$ & Average & STD & $n$ & Average & STD \\
\hline $0-2$ & 9 & 451 & 279 & 9 & 516 & 212 & 13 & 552 & 218 & 12 & 31.7 & 17.2 \\
$2-4$ & 6 & 295 & 195 & 8 & 447 & 240 & 8 & 448 & 141 & 8 & 28.3 & 6.8 \\
$4-6$ & 5 & 227 & 125 & 5 & 257 & 181 & 6 & 366 & 221 & 5 & 21.9 & 5.3 \\
$6-8$ & 5 & 225 & 163 & 4 & 120 & 119 & 6 & 248 & 96 & 4 & 19.9 & 8.3 \\
$8-10$ & 4 & 107 & 68.1 & 4 & 84.4 & 102 & 6 & 269 & 182 & 4 & 16.5 & 9.1 \\
$10-12$ & 5 & 88.3 & 50.9 & 3 & 44.3 & 35.9 & 5 & 176 & 109 & 4 & 21.1 & 10.4 \\
$12-14$ & 3 & 53.0 & 21.8 & 3 & 12.1 & 4.06 & 4 & 140 & 122 & 2 & 27.0 & 9.3 \\
$14-16$ & 3 & 66.6 & 106 & 3 & 8.32 & 5.83 & 5 & 141 & 89.9 & 3 & 22.2 & 13.8 \\
$16-18$ & 4 & 22.9 & 22.2 & 1 & 16.7 & & 5 & 97.5 & 101 & 3 & 17.1 & 10.7 \\
$18-20$ & 2 & 3.20 & 4.25 & 2 & 11.6 & 2.12 & 3 & 31.2 & 23.7 & 2 & 19.0 & 3.7 \\
$20-30$ & 6 & 15.2 & 14.0 & & & & 8 & 33.9 & 44.8 & 7 & 23.3 & 12.9 \\
\hline
\end{tabular}


Table 2: Average and standard deviation of $\mathrm{Hg}$ concentrations (ng/g, dry wt.) and relative content (\%) calculated from $\mathrm{HgT}$ at the F1-F5 fractions in the sediment cores from the polluted stations, activated sewage sludge (ASS) and background sediments ( $n=$ number of samples).

\begin{tabular}{|c|c|c|c|c|c|c|c|c|c|c|c|}
\hline & & $\mathrm{F}-1$ & & F-2 & & F-3 & & $F-4$ & & F-5 & \\
\hline$n$ & Depth (cm) & $\mathrm{Hg} \mathrm{ng/g}$ & $\%$ & $\mathrm{Hg} \mathrm{ng/g}$ & $\%$ & $\mathrm{Hg} \mathrm{ng/g}$ & $\%$ & $\mathrm{Hg} \mathbf{n g} / \mathrm{g}$ & $\%$ & $\mathrm{Hg} \mathbf{n g} / \mathrm{g}$ & $\%$ \\
\hline 15 & $0-2$ & $0.32 \pm 0.6$ & $0.1 \pm 0.1$ & $0.13 \pm 0.3$ & $0.03 \pm 0.07$ & $52.5 \pm 30.4$ & $15.4 \pm 6.6$ & $344 \pm 330$ & $75.5 \pm 9.8$ & $37.3 \pm 35.7$ & $9.0 \pm 8.8$ \\
\hline 13 & $2-4$ & $0.07 \pm 0.1$ & $0.02 \pm 0.05$ & $0.11 \pm 0.2$ & $0.02 \pm 0.05$ & $55.7 \pm 45$ & $15.6 \pm 9.8$ & $253 \pm 89$ & $75.2 \pm 8.8$ & $30.5 \pm 23.2$ & $9.1 \pm 7.2$ \\
\hline 14 & $6-8$ & $0.68 \pm 0.7$ & $0.5 \pm 0.9$ & $0.06 \pm 0.1$ & $0.05 \pm 0.11$ & $48.3 \pm 75.5$ & $16.1 \pm 9.5$ & $203 \pm 208$ & $72.4 \pm 12.5$ & $33.4 \pm 45.8$ & $10.9 \pm 12.9$ \\
\hline 14 & $8-10$ & $1.23 \pm 2.3$ & $0.7 \pm 1.1$ & $0.05 \pm 0.1$ & $0.06 \pm 0.10$ & $31 \pm 30.5$ & $13.9 \pm 5.6$ & $180 \pm 206$ & $73.9 \pm 10.1$ & $53.3 \pm 104$ & $11.5 \pm 13.4$ \\
\hline 8 & $10-12$ & $0.32 \pm 0.53$ & $0.3 \pm 0.6$ & $0.04 \pm 0.07$ & $0.05 \pm 0.10$ & $7.33 \pm 6.48$ & $14.0 \pm 12.1$ & $66.3 \pm 46.3$ & $79.8 \pm 14.1$ & $3.72 \pm 5.7$ & $5.8 \pm 5.6$ \\
\hline 6 & $12-14$ & $1.09 \pm 1.23$ & $2.9 \pm 3.2$ & $0.05 \pm 0.08$ & $0.57 \pm 0.66$ & $7.62 \pm 6.1$ & $11 \pm 3.3$ & $75.2 \pm 75.2$ & $83 \pm 3.6$ & $3.96 \pm 5.6$ & $2.8 \pm 2.6$ \\
\hline 6 & $14-16$ & $0.67 \pm 0.64$ & $1.3 \pm 1.3$ & $0.1 \pm 0.09$ & $0.31 \pm 0.37$ & $7.59 \pm 6.83$ & $11.1 \pm 4.1$ & $50.6 \pm 30.2$ & $85.8 \pm 3.1$ & $0.93 \pm 1.5$ & $1.5 \pm 2.4$ \\
\hline 6 & $16-18$ & $0.92 \pm 0.66$ & $1.4 \pm 0.2$ & $0.1 \pm 0.08$ & $0.53 \pm 0.69$ & $7.88 \pm 6.79$ & $12.3 \pm 6.2$ & $57.1 \pm 38.9$ & $83.4 \pm 4.8$ & $2.24 \pm 3.45$ & $2.5 \pm 3.9$ \\
\hline 8 & $18-22$ & $0.64 \pm 0.37$ & $3.4 \pm 1.3$ & $0.07 \pm 0.08$ & $0.36 \pm 0.40$ & $2.94 \pm 1.03$ & $17.4 \pm 5.1$ & $13.4 \pm 6.7$ & $70.9 \pm 8.4$ & $1.22 \pm 1.05$ & $7.9 \pm 7.1$ \\
\hline 5 & ASS & $0.46 \pm 0.7$ & $0.03 \pm 0.05$ & $11.5 \pm 14.7$ & $1.0 \pm 1.3$ & $271 \pm 55$ & $21.7 \pm 2.8$ & $867 \pm 48$ & $70.3 \pm 3.9$ & $87.8 \pm 44.7$ & $6.9 \pm 3.1$ \\
\hline 10 & Background & $0.13 \pm 021$ & $0.63 \pm 0.92$ & $0.06 \pm 0.06$ & $0.44 \pm 0.62$ & $9.3 \pm 5$ & $50.5 \pm 16.8$ & $8.28 \pm 5.59$ & $43.7 \pm 16.2$ & $1.43 \pm 2.94$ & $4.8 \pm 7.1$ \\
\hline
\end{tabular}


Table 3: Comparison among the relative distributions of $\mathrm{Hg}(\%)$ in fractions F3-F5, at the polluted stations (P.S), the ASS and the background station (B.S).

\begin{tabular}{|c|c|c|c|}
\hline Matrix & F3 & F4 & F5 \\
\hline P.S & $14.9 \pm 7.9$ & $75.9 \pm 10.3$ & $8.2 \pm 9.3$ \\
ASS & $21.7 \pm 2.8$ & $70.3 \pm 3.9$ & $6.9 \pm 3.2$ \\
B.S & $50.5 \pm 16.8$ & $43.7 \pm 16.2$ & $4.8 \pm 7.1$ \\
\cline { 2 - 4 } & B.S $>$ ASS $>$ P.S & P.S $>$ ASS $>$ B.S & B.S $=P . S=A S S$ \\
\hline
\end{tabular}




\section{List of Figures}

Figure 1: Area of study and location of the sampling stations at the marine sewage sludge outfall.

Fig.2: Water and organic carbon content in the sediments from the polluted stations $(0,3,21)$ and the background station (29), at representative surveys of spring (May) and fall (August-October) conditions.

Fig.3: HgT concentrations in sediment cores at the polluted stations $(0,3,21)$ and background station (29), in all surveys. Note different X scale at station 29.

Fig. 4: Vertical distribution of average MeHg concentrations in sediments from the polluted stations $(0,21)$ and the background station (29) (May-02, October-02 and September-03).

Fig: 5: Linear regression between $\mathrm{MeHg}$ and $\mathrm{HgT}$ (ng/g) in sediment cores from stations $0(n=21), 3(n=13), 21(n=21)$ and $29(n=6)$, from all surveys. Note different Y axis scales.

Fig.6: Hg distribution among F1-F5 fractions at the background (BG) station, the polluted stations, activated sewage sludge (ASS) and 2 certified reference material:

NIST-2781=Domestic Sludge and IAEA-405=Estuarine sediment $(\mathrm{n}=$ number of samples; at the polluted stations the average of all results is presented). 
Fig. 7: Vertical distribution of relative $\mathrm{Hg}$ content $(\%)$ in each fraction, at the polluted stations.

Fig. 8: Linear regression between relative $\mathrm{Hg}$ content $(\%)$ in the different fractions $(n=50)$ at the polluted stations. Note different y axis for F1 vs. F5. 
Figure 1: Area of study and location of the sampling stations at the marine sewage sludge outfall.

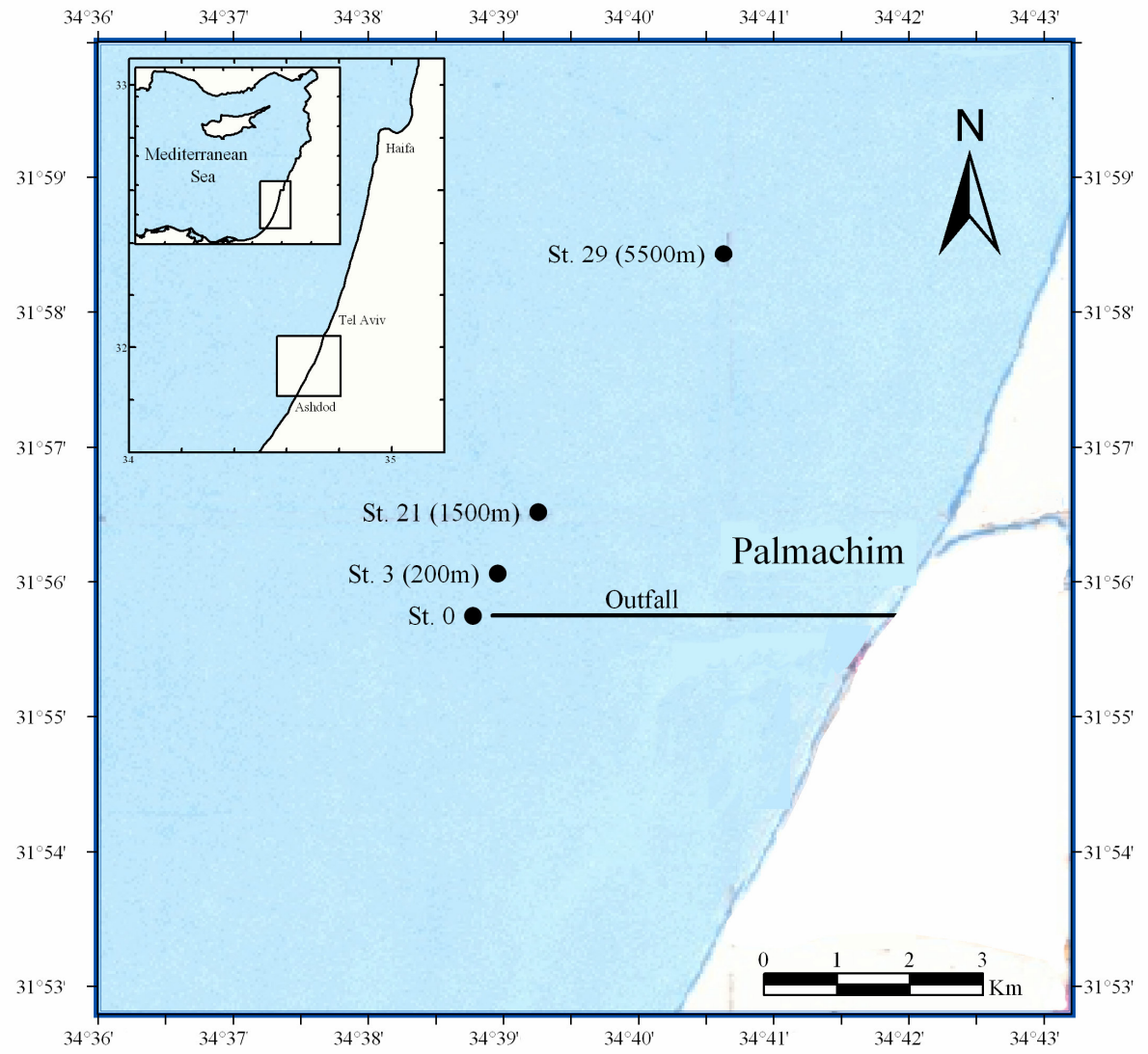


Fig.2: Water and organic carbon content in the sediments from the polluted stations $(0,3,21)$ and the background station (29), at representative surveys of spring (May) and fall (August-October) conditions.
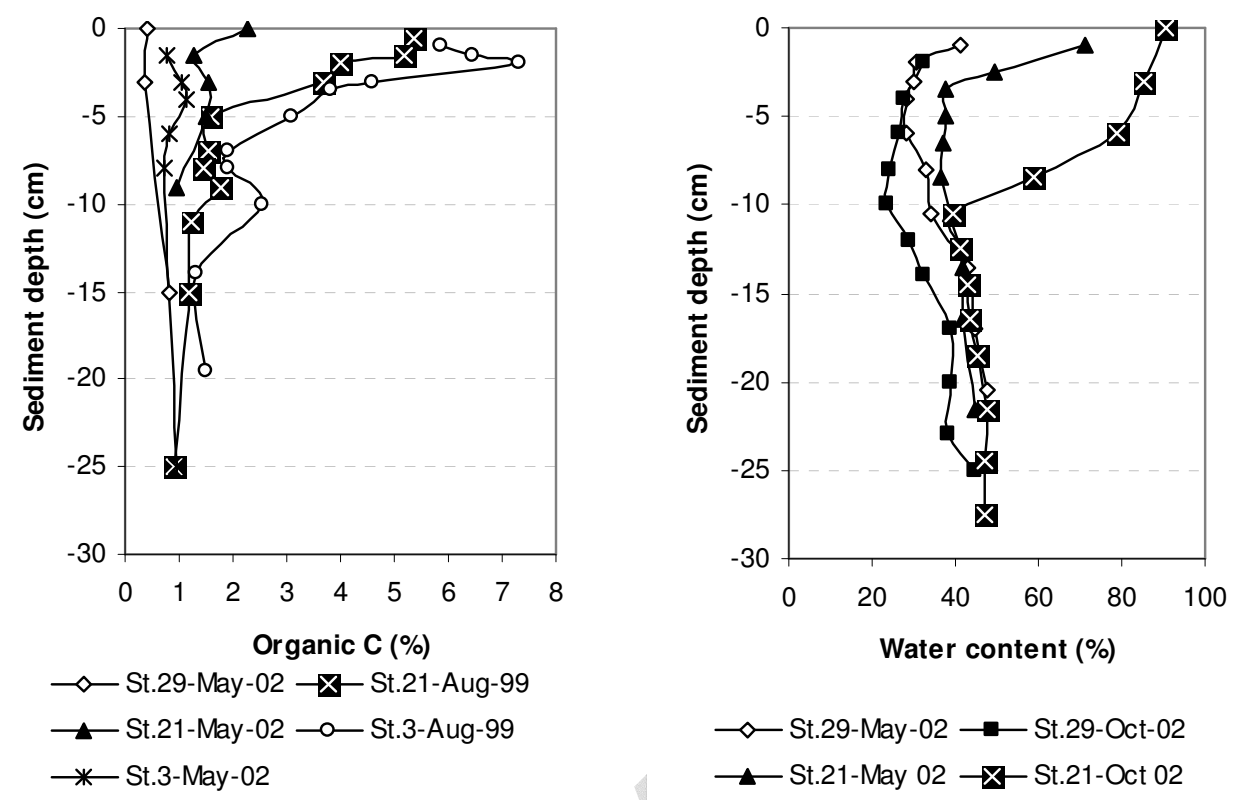
Fig. $3 \mathrm{HgT}$ concentrations in sediment cores at the polluted stations $(0,3,21)$ and background station (29), in all surveys. Note different X scale at station 29.
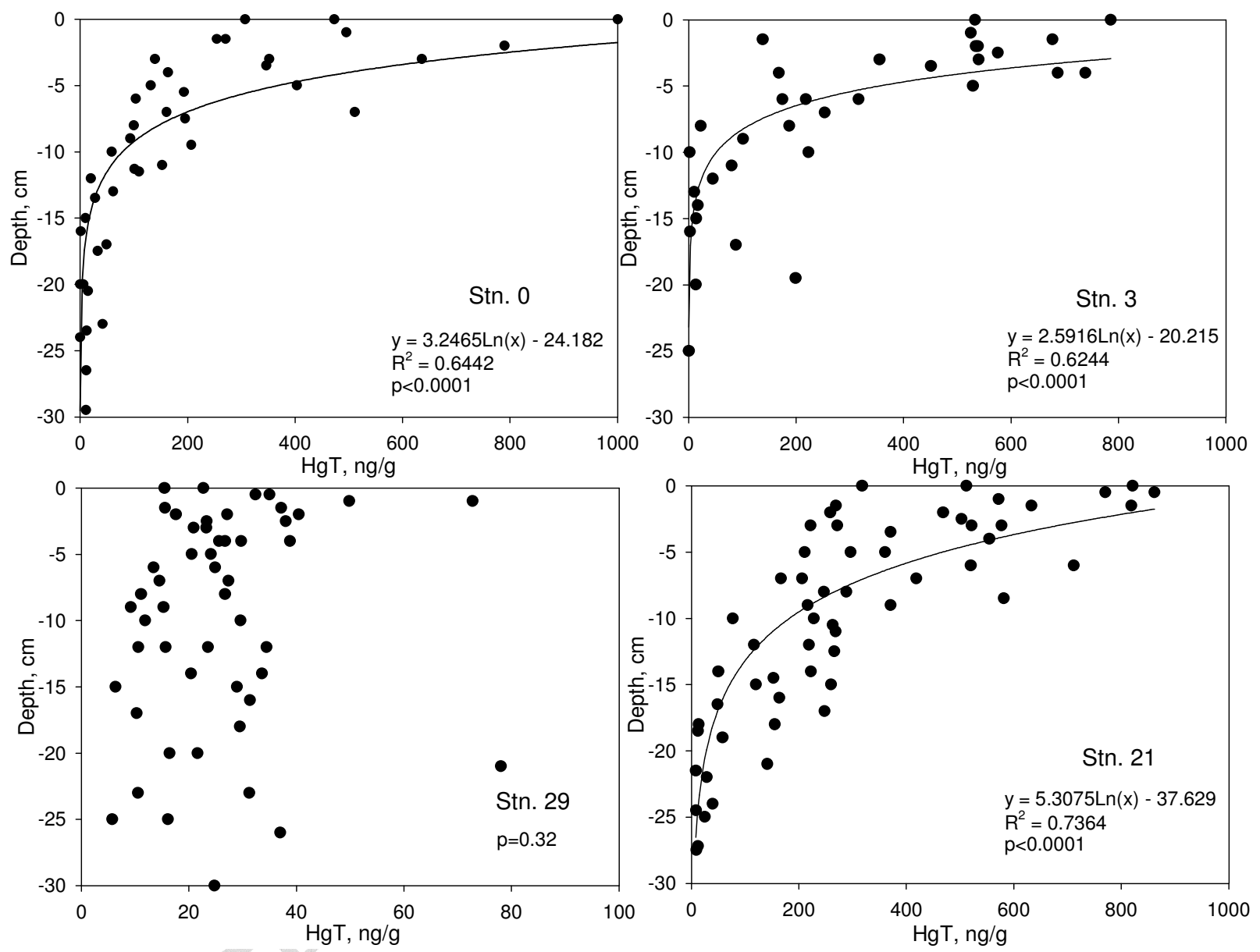
Fig. 4: Vertical distribution of average $\mathrm{MeHg}$ concentrations in sediments from the polluted stations $(0,21)$ and the background station (29) (May-02, October-02 and September-03).

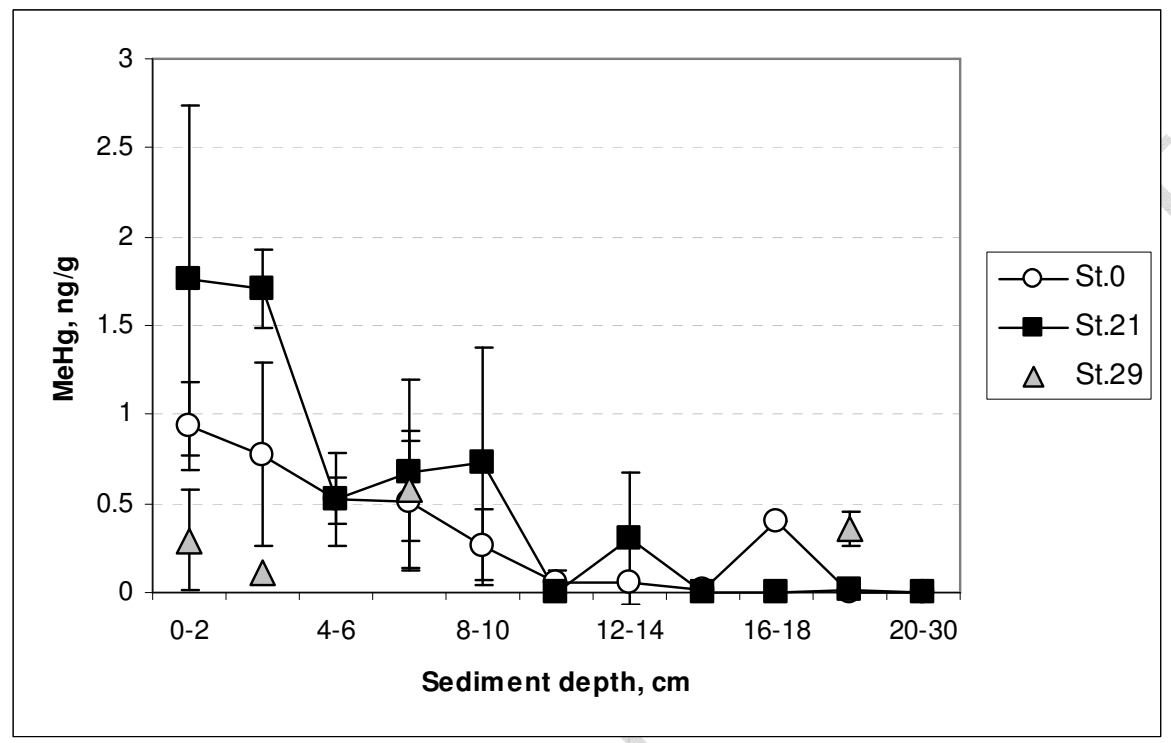

Fig: 5: Linear regression between $\mathrm{MeHg}$ and $\mathrm{HgT}$ (ng/g dry wt.) in sediment cores from the polluted stations $0(n=21), 3(n=13), 21(n=21)$ and the background station $29(n=6)$, from all surveys. Note different $Y$ axis scales.

St. 0

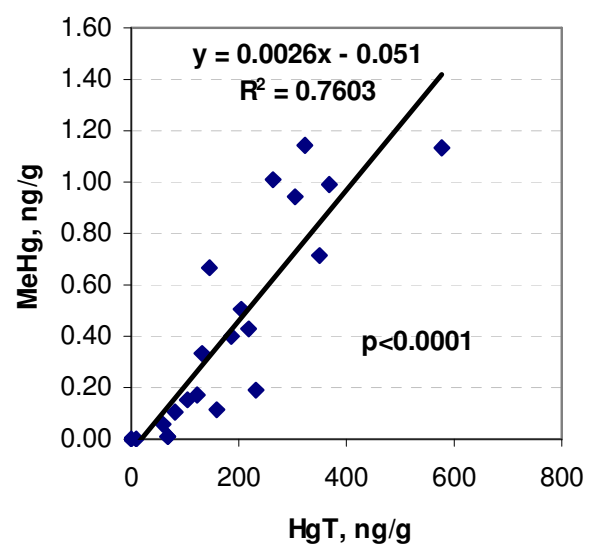

St. 3

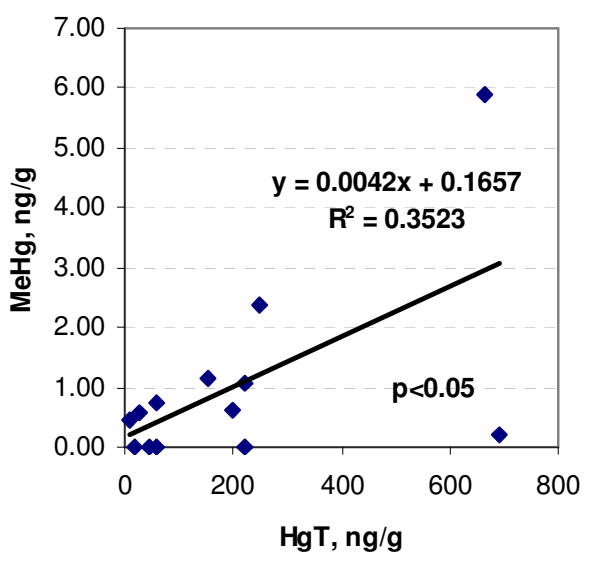


St. 21

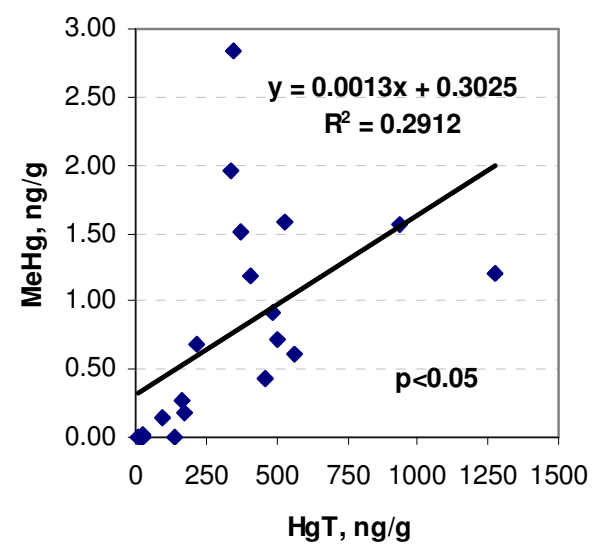

St. 29

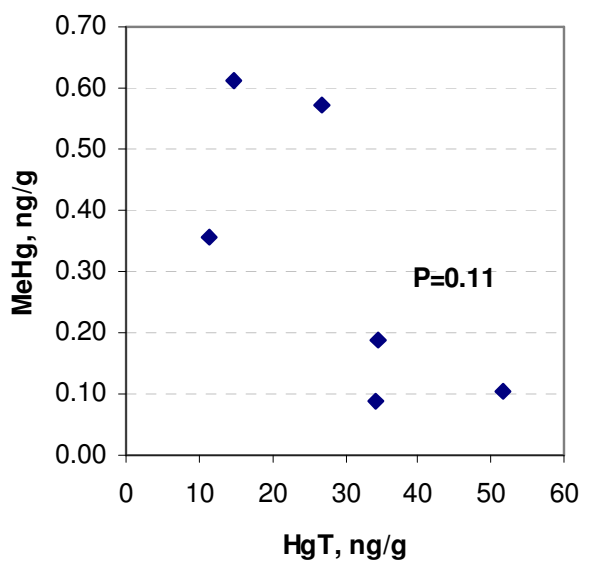

Fig.6: Hg distribution among F1-F5 fractions at the background (BG) station, the polluted stations, activated sewage sludge (ASS) and 2 certified reference material: NIST-2781=Domestic Sludge, and IAEA-405=Estuarine sediment $(\mathrm{n}=$ number of samples; at the polluted stations the average of all results is presented).

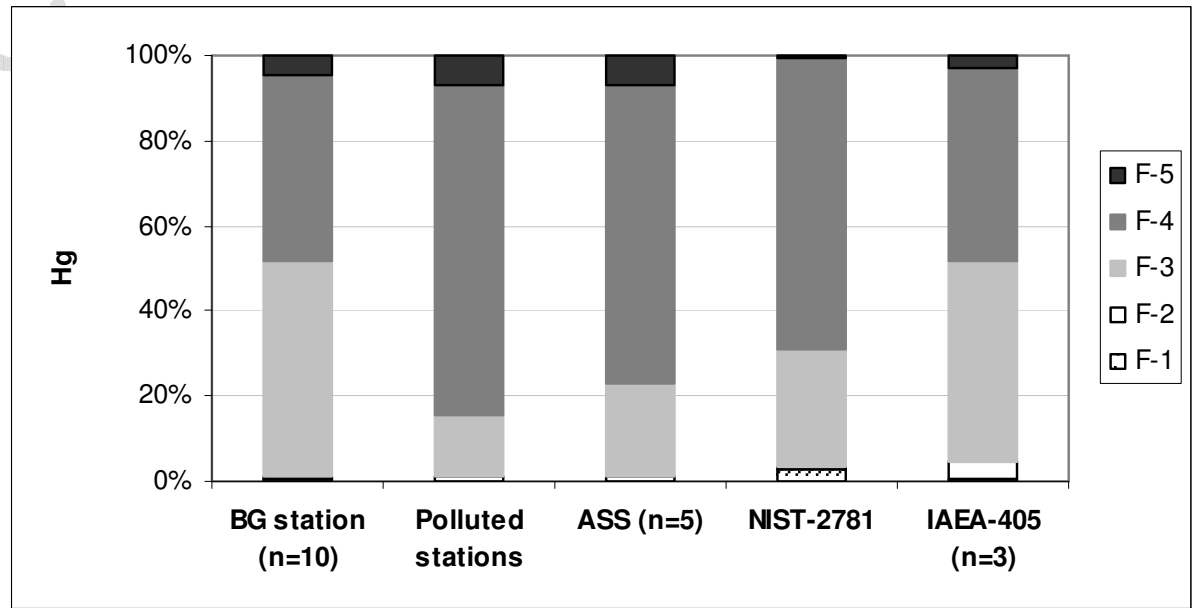


Fig. 7: Vertical distribution of relative $\mathrm{Hg}$ content (\%) in each fraction, at the polluted

stations.

F1

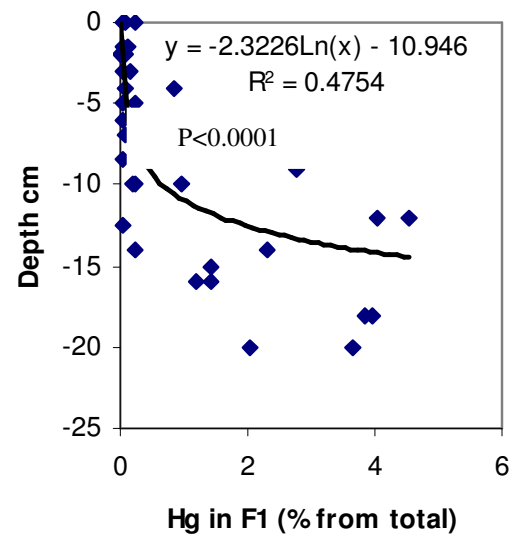

F4



$\mathrm{Hg}$ in $\mathrm{F} 4$ (\% from total)
F3



F5

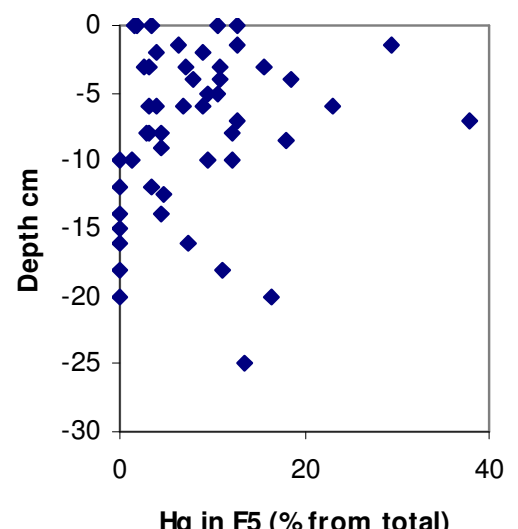

$\mathrm{Hg}$ in $\mathrm{F} 5$ (\% from total) 
Fig. 8: Linear regression between relative $\mathrm{Hg}$ content (\%) in the different fractions $(\mathrm{n}=50)$ at the polluted stations. Note different $\mathrm{Y}$ axis for F1 vs. F5.
